American Journal of Animal and Veterinary Sciences 6 (1): 1-6, 2011

ISSN $1557-4555$

(C) 2011 Science Publications

\title{
Plasma Thyroid Hormone Concentrations and pH Values of Some GI-Tract Segments of Broilers Fed on Different Dietary Citric Acid and Microbial Phytase Levels
}

\author{
Rouhollah Nourmohammadi, Seyed Mohammad Hosseini, \\ Hamed Saraee and Alireza Arab \\ Department of Animal Science, College of Agriculture, \\ University of Birjand, Birjand, Iran
}

\begin{abstract}
Problem statement: An experiment was conducted to study the effect of microbial phytase supplementation and citric acid on thyroid activity, relative weight of lymphoid organs and $\mathrm{pH}$ values of some GI-tract segments in broiler chickens fed corn-soybean meal based diets. Approach: The data was analyzed using a Randomized Complete Block Design (RCBD) with factorial arrangement of $3 \times 3$, three levels of citric acids $\left(0,3\right.$ and 6\%) and three levels of phytase $\left(0,500\right.$ and $\left.1000 \mathrm{IU} \mathrm{kg}^{-1}\right)$. There were three replicates (with ten chicks in each replicate) for each treatment. A total of 270 Ross 308 broiler chicks were used. Results: Addition of citric acid to diets caused significant decrease in $\mathrm{pH}$ values of crop, gizzard, duodenum, jejunum and ileum $(\mathrm{p}<0.05)$ and caused significant increase $(p<0.01)$ in plasma triiodothyronine $\left(T_{3}\right)$ concentration, $T_{3}: T_{4}$ ratio and relative weight of bursa and thymus, but had no significant effect on thyroxin $\left(\mathrm{T}_{4}\right)$ concentrations. Microbial phytase significantly increased relative weight of thymus $(p<0.01$ ), but had no significant effects on thyroid gland activity, relative weight of bursa and values of $\mathrm{pH}$ in different parts of the GI-tract. Conclusion: Broiler chicks fed on acidifiers diets had better immune response resistance that lead to immunological advances. Also, decreasing $\mathrm{pH}$ in GI-tract by CA caused a beneficial effect in the inhibition of intestinal bacteria competition.
\end{abstract}

Key words: Broilers fed, phytase supplementation, $\mathrm{pH}$ value, thyroid hormones, intestinal bacteria, plasma triiodothyronine, GI-tract segments, thyroid activity, Microbial Phytases (MP), broiler chicks, Citric acid (CA), Analysis Of Variance (ANOVA)

\section{INTRODUCTION}

Phytate and phytate-bound phosphorus (P) are present in all poultry diets and the partial availability of phytate-P has long been recognized (Lowe et al., 1939). Possibly, Warden and Schaible (1962) were the first to show that exogenous phytase enhances phytate-P utilization and bone mineralization in broiler chickens. Nevertheless, three decades elapsed before an Aspergillus niger derived phytase feed enzyme with the capacity to liberate phytate bound $\mathrm{P}$ to reduce $\mathrm{P}$ excretion that was commercially introduced in 1991. Then, the use of Microbial Phytases (MP) would be considered to areas where financial penalties on excessive $\mathrm{P}$ levels Production from intensive pig and poultry units were imposed (Chesson, 1993). In contrast, the inclusion of phytase feed enzymes in monogastric diets has been far more widely accepted and now exceeds that of NSP degrading enzymes.
Phytase feed enzymes have more general application as their substrate is consistently present in pig and poultry diets and their dietary inclusion economically effect bioavailability of $\mathrm{P}$ and reduces the $\mathrm{P}$ load in the environment. Also, prohibition of animal origin protein meals accelerate $\mathrm{P}$ acceptance as phytase feed enzymes in certain countries. Phytase is naturally found in a number of seeds including cereals, legume, byproducts, other feedstuffs and microbial sources (Viveros et al., 2000). Supplementation of diets with MP has known to increase availability of phytate $\mathrm{P}$ and Zn in chicks (Sebastian et al., 1996; Ravindran et al., 2000). Phytase increases availability and retention of $\mathrm{Ca}$, improves absorption and retention of $\mathrm{Mg}, \mathrm{Cu}$ and Fe (Sebastian et al., 1996).

Previous researches have shown that poultry digestive tract acidity is not desirable to complete hydrolyze or establish phytate by phytase (Brenes et al., 2003). Citric acid (CA) may change the intestinal $\mathrm{pH}$

Corresponding Author: Rouhollah Nourmohammadi, Department of Animal Science, College of Agriculture, University of Birjand, Birjand, P.O. Box 331/97175, Iran Tel: +989151601400 Fax: +985612254050 
and improve phytase enzyme activity, because the phytase efficiency is correlated with both acidity and concentration of other free cations (Nourmohammadi et al., 2010a). Therefore, it might be used with chelated organic acids to enable intensification of phytase efficiency. Kemme et al. (1998) reported that phytase efficiency is related to plant or microbial sources, in hydrolyzed phytate and gut $\mathrm{pH}$ and time duration. Therefore, between CA and MP may have been synergistic effect. This study was carried out to investigate the effect of supplementing diet with both $\mathrm{MP}$ and CA and their interaction on plasma hormones concentration, relative weight of lymphoid organs and $\mathrm{pH}$ values of some gastrointestinal tract segments.

\section{MATERIALS AND METHODS}

Diets, birds and experimental design: This experiment took place in Poultry Research Unit and nutrition laboratory at University of Birjand, Iran. Two hundred and seventy day-old male chicks (Ross-308) were obtained from a commercial hatchery, weighed on arrival and randomly assigned to 27 pens of 10 birds each. The experiment was carried out using a randomized complete block design (RCBD) with factorial arrangement of $3 \times 3$, three levels of CA $(0,30$ and $6 \%)$ and three levels of phytase $(0,500$ and 1000 IU $\mathrm{kg}^{-1}$ MP enzyme). There were 9 experimental treatments, 3 replicates with ten chicks in each replicate. Feed and water were provided ad libitum and a continuous lighting schedule were used throughout the experimental period. A basal diet (without phytase enzyme or CA), was formulated with corn-soybean meal from 7 to 21 and 22 to 42 day periods according to National Research Council recommendations. Diets were provided in the mash form. Broiler chicks were fed the following diets with equal energy and protein levels: $\mathrm{T}_{1}$ ) basal diet, $\mathrm{T}_{2}$ ) basal diet $+500 \mathrm{IU} \mathrm{kg}^{-1} \mathrm{MP}$, $\mathrm{T}_{3}$ ) basal diet $+1000 \mathrm{IU} \mathrm{kg}^{-1} \mathrm{MP}, \mathrm{T}_{4}$ ) basal diet $+3 \%$ CA, $\mathrm{T}_{5}$ ) basal diet $+3 \% \mathrm{CA}+500 \mathrm{MP} \mathrm{IU} \mathrm{kg}{ }^{-1}, \mathrm{~T}_{6}$ ) basal diet $+3 \% \mathrm{CA}+1000 \mathrm{IU} \mathrm{kg}^{-1} \mathrm{MP}, \mathrm{T}_{7}$ ) basal diet $+6 \% \mathrm{CA}$, $\mathrm{T}_{8}$ ) basal diet $+6 \% \mathrm{CA}+500 \mathrm{IU} \mathrm{kg}^{-1} \mathrm{MP}$ and $\mathrm{T}_{9}$ ) basal diet $+6 \% \mathrm{CA}+1000 \mathrm{IU} \mathrm{kg}^{-1}$ MP. CA was supplied as monohydrate with $99.5 \%$ purity and phytase (Natuphos ${ }^{\circledR}$ 500, BASF Corp., Mt. Live, Nj), diet source also had 10,000 active phytase unit per gram.

Samples collection and analysis: At the end of the experimental period ( $42 \mathrm{~d}$ of age), two birds per replicate ( 6 birds per treatment) were selected randomly and killed by cervical dislocation. Blood samples (approx. $10 \mathrm{ml}$ ) were collected in heparinized vacuitainer tubes for measuring plasma hormones concentration (triiodothyronine and thyroxin). Immediately after collection, tubes were placed in an ice bath and transferred to the laboratory. Plasma was harvested subsequently after centrifuging the whole blood samples at $3000 \mathrm{rpm}$ for $15 \mathrm{~min}$. The heparinized plasma samples were stored at $-20^{\circ} \mathrm{C}$ in Eppendorf tubes and analyzed subsequently. The triiodothyronine $\left(\mathrm{T}_{3}\right)$ and thyroxin $\left(\mathrm{T}_{4}\right)$ concentrations in the plasma samples were determined by radioimmunoassay (RIA) using the procedure described by Darras et al. (1992).

At the end of the experimental period, two birds per replicate (6 birds per treatment) were taken randomly, weighed and killed by cervical dislocation, then scalded and defeathered. Thymus (all lobes of both sides) and bursa were removed and their relative percentages of live body weights were calculated.

PH Values for different segments of the gastrointestinal tract (GI-tract) were measured immediately by using a digital $\mathrm{pH}$ meter. $10 \mathrm{~g}$ of contents from crop, gizzard, duodenum, jejunum and ileum were collected aseptically in $90 \mathrm{ml}$ sterilized physiological saline (1: 10 dilution) and their $\mathrm{pHs}$ were determined (Al-Natour and Alshawabkeh, 2005).

Statistical analysis: The data were subjected to an Analysis Of Variance (ANOVA) through fitting general linear model (GLM) using SAS ${ }^{\circledR}$ (SAS Institute, 2000) software and the corresponding means were compared by Tukey-Kramer test. The statistical model was as follows:

$\mathrm{Y}_{\mathrm{ijk} k}=\mu+\mathrm{CA}_{\mathrm{i}}+\mathrm{MP}_{\mathrm{j}}+(\mathrm{CA} \times \mathrm{MP})_{\mathrm{ij}}+\mathrm{B}_{\mathrm{k}}+\mathrm{e}_{\mathrm{ijkl}}$

Where

$\mathrm{Y}_{\mathrm{ijk} \mathrm{l}}=$ The individual observation

$\mu=$ The experimental mean

$\mathrm{CA}_{\mathrm{i}}=$ The Citric Acid effect

$\mathrm{MP}_{\mathrm{j}}=$ The Microbial Phytase effect

$\mathrm{B}_{\mathrm{k}}=$ The block effect

$\mathrm{e}_{\mathrm{ijkl}}=$ The error term with mean 0 and variance $\sigma_{\mathrm{e}}^{2}$.

\section{RESULTS}

The main effects results of CA and MP on plasma hormones and relative weight of lymphoid organs are shown in Table 1. The results indicated that CA caused significant increase in $T_{3}, T_{3}: T_{4}$ ratio, bursa and thymus $(p<0.01)$, but had no significant effect on plasma $T_{4}$ concentration. Also, MP caused an increase in relative weight of thymus $(p<0.01)$ although MP main effect was not significant for $\mathrm{T}_{3}, \mathrm{~T}_{4}, \mathrm{~T}_{3}: \mathrm{T}_{4}$ ratio and relative weight of bursa. 
American J. Animal \& Vet. Sci., 6 (1): 1-6, 2011

Table 1: The main effects of CA and MP on plasma thyroid hormones and relative weight of lymphoid organs ( $\mathrm{g} \mathrm{kg}^{-1}$ of live weight)

\begin{tabular}{|c|c|c|c|c|c|}
\hline \multirow[b]{2}{*}{ Main effects } & \multicolumn{3}{|c|}{ Thyroid gland activity } & \multicolumn{2}{|c|}{ Lymphoid organs } \\
\hline & $\mathrm{T}_{3}\left(\mathrm{ng} \mathrm{mL}^{-1}\right)$ & $\mathrm{T}_{4}\left(\mathrm{ng} \mathrm{mL}^{-1}\right)$ & $\mathrm{T}_{3}: \mathrm{T}_{4}$ & Bursa & Thymus \\
\hline \multicolumn{6}{|l|}{ MP $\left(\mathrm{IU} \mathrm{kg}^{-1}\right)$} \\
\hline 0 & 1.702 & 16.133 & 0.105 & 0.27 & $0.33^{\mathrm{b}}$ \\
\hline 500 & 1.704 & 16.251 & 0.105 & 0.28 & $0.35^{\mathrm{a}}$ \\
\hline 1000 & 1.701 & 16.245 & 0.105 & 0.28 & $0.35^{\mathrm{a}}$ \\
\hline \multicolumn{6}{|l|}{ CA (\%) } \\
\hline 0 & $1.571^{\mathrm{c}}$ & 16.234 & $0.097^{\mathrm{c}}$ & $0.25^{\mathrm{c}}$ & $0.28^{\mathrm{c}}$ \\
\hline 3 & $1.718^{\mathrm{b}}$ & 16.141 & $0.106^{\mathrm{b}}$ & $0.27^{\mathrm{b}}$ & $0.34^{\mathrm{b}}$ \\
\hline 6 & $1.818^{\mathrm{a}}$ & 16.255 & $0.112^{\mathrm{a}}$ & $0.31^{\mathrm{a}}$ & $0.41^{\mathrm{a}}$ \\
\hline SEM & 0.0020 & 0.0643 & 0.0005 & 0.003 & 0.005 \\
\hline \multicolumn{6}{|l|}{ Probabilities } \\
\hline MP & NS & NS & NS & NS & 0.01 \\
\hline $\mathrm{CA}$ & 0.01 & NS & 0.01 & 0.01 & 0.01 \\
\hline $\mathrm{MP} \times \mathrm{CA}$ & NS & NS & NS & NS & NS \\
\hline
\end{tabular}

Mean values within a column with no common superscript differ significantly from each other $(\mathrm{P}<0.05), \mathrm{T}_{3}=$ triiodothyronine, $\mathrm{T}_{4}=$ thyroxin, $\mathrm{MP}=$ microbial phytase, $\mathrm{CA}=$ citric acid, $\mathrm{SEM}=$ standard error of mean, $\mathrm{NS}=$ not significant

Table 2: Interaction effects between CA and MP on plasma thyroid hormones and relative weight of lymphoid organs ( $\mathrm{g} \mathrm{kg}^{-1}$ of live weight) Treatments Thyroid gland activity Lymphoid organs

\begin{tabular}{|c|c|c|c|c|c|c|}
\hline & & \\
\hline $\mathrm{CA}(\%)$ & MP (IU kg $\left.{ }^{-1}\right)$ & $\mathrm{T}_{3}\left(\mathrm{ng} \mathrm{mL}^{-1}\right)$ & $\mathrm{T}_{4}\left(\mathrm{ng} \mathrm{mL}^{-1}\right)$ & $\mathrm{T}_{3}: \mathrm{T}_{4}$ & Bursa & Thymus \\
\hline 0 & 0 & $1.571^{\mathrm{c}}$ & 16.228 & $0.097^{\mathrm{c}}$ & $0.24^{\mathrm{b}}$ & $0.27^{\mathrm{e}}$ \\
\hline 0 & 500 & $1575^{\mathrm{c}}$ & 16.247 & $0.097^{\mathrm{c}}$ & $0.26^{\mathrm{b}}$ & $0.28^{\mathrm{e}}$ \\
\hline 0 & 1000 & $1.569^{\mathrm{c}}$ & 16.228 & $0.097^{\mathrm{c}}$ & $0.26^{\mathrm{b}}$ & $0.29^{\mathrm{de}}$ \\
\hline 3 & 0 & $1.719^{\mathrm{b}}$ & 15.918 & $0.108^{\mathrm{ab}}$ & $0.27^{\mathrm{b}}$ & $0.33^{\text {cd }}$ \\
\hline 3 & 500 & $1.718^{\mathrm{b}}$ & 16.251 & $0.106^{\mathrm{b}}$ & $0.27^{\mathrm{b}}$ & $0.35^{\mathrm{bc}}$ \\
\hline 3 & 1000 & $1.717^{\mathrm{b}}$ & 16.254 & $0.106^{b}$ & $0.27^{\mathrm{b}}$ & $0.35^{\mathrm{bc}}$ \\
\hline 6 & 0 & $1.817^{\mathrm{a}}$ & 16.254 & $0.112^{\mathrm{a}}$ & $0.31^{\mathrm{a}}$ & $0.38^{\mathrm{ab}}$ \\
\hline 6 & 500 & $1.821^{\mathrm{a}}$ & 16.256 & $0.112^{\mathrm{a}}$ & $0.32^{\mathrm{a}}$ & $0.42^{\mathrm{a}}$ \\
\hline 6 & 1000 & $1.817^{\mathrm{a}}$ & 16.255 & $0.112^{\mathrm{a}}$ & $0.30^{\mathrm{a}}$ & $0.42^{\mathrm{a}}$ \\
\hline SEM & & 0.0034 & 0.1113 & 0.0005 & 0.006 & 0.009 \\
\hline
\end{tabular}

Mean values within a column with no common superscript differ significantly from each other $(\mathrm{P}<0.05), \mathrm{T}_{3}=$ triiodothyronine, $\mathrm{T}_{4}=$ thyroxin, $\mathrm{MP}=$ microbial phytase, $\mathrm{CA}=$ citric acid, $\mathrm{SEM}=$ standard error of mean, $\mathrm{NS}=$ not significant

Table 3:The main effects of CA and MP on $\mathrm{pH}$ values of some gastrointestinal tract segments in broiler chicks

\begin{tabular}{|c|c|c|c|c|c|}
\hline Main effects & Crop & Gizzard & Duodenum & Jejunum & Ileum \\
\hline \multicolumn{6}{|l|}{$\overline{\mathrm{MP}\left(\mathrm{IU} \mathrm{kg} \mathrm{kg}^{-1}\right)}$} \\
\hline 0 & 5.00 & 3.16 & 5.77 & 6.45 & 7.20 \\
\hline 500 & 5.02 & 3.16 & 5.77 & 6.45 & 7.19 \\
\hline 1000 & 5.03 & 3.17 & 5.77 & 6.45 & 7.19 \\
\hline \multicolumn{6}{|l|}{ CA (\%) } \\
\hline 0 & $5.17^{\mathrm{a}}$ & $3.21^{\mathrm{a}}$ & $5.80^{\mathrm{a}}$ & $6.63^{\mathrm{a}}$ & $7.22^{\mathrm{a}}$ \\
\hline 3 & $5.00^{\mathrm{b}}$ & $3.19^{\mathrm{a}}$ & $5.79^{\mathrm{a}}$ & $6.49^{\mathrm{b}}$ & $7.21^{\mathrm{a}}$ \\
\hline 6 & $4.89^{c}$ & $3.09^{\mathrm{b}}$ & $5.71^{\mathrm{b}}$ & $6.23^{c}$ & $7.16^{\mathrm{b}}$ \\
\hline SEM & 0.012 & 0.006 & 0.003 & 0.007 & 0.004 \\
\hline \multicolumn{6}{|l|}{ Probabilities } \\
\hline MP & NS & NS & NS & NS & NS \\
\hline $\mathrm{CA}$ & 0.01 & 0.01 & 0.01 & 0.01 & 0.01 \\
\hline $\mathrm{MP} \times \mathrm{CA}$ & NS & NS & NS & NS & NS \\
\hline
\end{tabular}

Mean values within a column with no common superscript differ significantly from each other $(\mathrm{P}<0.05), \mathrm{SEM}=$ standard error of mean, $\mathrm{MP}=$ microbial phytase, $\mathrm{CA}=$ citric acid, $\mathrm{NS}=$ not significant

Table 4: Interaction effect between $\mathrm{CA}$ and $\mathrm{MP}$ on $\mathrm{pH}$ values of some gastrointestinal tract segments in broiler chicks Treatments

\begin{tabular}{|c|c|c|c|c|c|c|}
\hline CA (\%) & MP (IU kg $\left.{ }^{-1}\right)$ & Crop & Gizzard & Duodenum & Jejunum & Ileum \\
\hline 0 & 0 & $5.17^{\mathrm{a}}$ & $3.21^{\mathrm{a}}$ & $5.81^{\mathrm{a}}$ & $6.64^{\mathrm{a}}$ & $7.22^{\mathrm{a}}$ \\
\hline 0 & 500 & $5.17^{\mathrm{a}}$ & $3.20^{\mathrm{a}}$ & $5.80^{\mathrm{a}}$ & $6.63^{\mathrm{a}}$ & $7.22^{\mathrm{a}}$ \\
\hline 0 & 1000 & $5.17^{\mathrm{a}}$ & $3.21^{\mathrm{a}}$ & $5.80^{\mathrm{a}}$ & $6.63^{\mathrm{a}}$ & $7.22^{\mathrm{a}}$ \\
\hline 3 & 0 & $4.99^{\mathrm{b}}$ & $3.20^{\mathrm{a}}$ & $5.80^{\mathrm{a}}$ & $6.48^{\mathrm{b}}$ & $7.21^{\mathrm{a}}$ \\
\hline 3 & 500 & $5.00^{\mathrm{b}}$ & $3.20^{\mathrm{a}}$ & $5.79^{\mathrm{a}}$ & $6.50^{\mathrm{b}}$ & $7.20^{\mathrm{ab}}$ \\
\hline 3 & 1000 & $5.00^{\mathrm{b}}$ & $3.18^{\mathrm{a}}$ & $5.79^{\mathrm{a}}$ & $6.49^{\mathrm{b}}$ & $7.21^{\mathrm{a}}$ \\
\hline 6 & 0 & $4.85^{\mathrm{c}}$ & $3.08^{\mathrm{b}}$ & $5.72^{\mathrm{b}}$ & $6.23^{\mathrm{c}}$ & $7.17^{\mathrm{bc}}$ \\
\hline 6 & 500 & $4.90^{\mathrm{bc}}$ & $3.09^{\mathrm{b}}$ & $5.72^{\mathrm{b}}$ & $6.23^{\mathrm{c}}$ & $7.16^{\mathrm{c}}$ \\
\hline 6 & 1000 & $4.92^{\mathrm{bc}}$ & $3.11^{\mathrm{b}}$ & $5.71^{\mathrm{b}}$ & $6.23^{\mathrm{c}}$ & $7.15^{\mathrm{c}}$ \\
\hline SEM & & 0.022 & 0.010 & 0.004 & 0.012 & 0.007 \\
\hline
\end{tabular}

Mean values within a column with no common superscript differ significantly from each other $(\mathrm{P}<0.05), \mathrm{SEM}=$ standard error of mean, $\mathrm{MP}=$ microbial phytase, $\mathrm{CA}=$ citric acid, $\mathrm{NS}=$ not significant 
Moreover, the present findings showed that there were significant differences between $\mathrm{T}_{3}, \mathrm{~T}_{3}: \mathrm{T}_{4}$ ratio and relative weight of bursa and thymus $(\mathrm{p}<0.05)$, (Table 2). Current study data indicated that CA significantly decreased $\mathrm{pH}$ value of GI-tract segments $(\mathrm{p}<0.01)$, but MP had no significant effect on $\mathrm{pH}$ values (Table 3). Also, the results showed that there was significant effect between treatments for $\mathrm{pH}$ values of GI-tract parts $(\mathrm{p}<0.05)$ (Table 4).

\section{DISCUSSION}

It is well known that bursa and thymus are considered as parts of the immunity system (Sturkie, 1999) and this system is responsible for producing cells that protect the birds from the invaded microorganism. From Table 1, it is clearly observed that supplemental MP and CA significantly increased the relative weight of both primary lymphoid organs (bursa and thymus). Increasing the weight of thymus may be due to the impact of MP on the functional activities of the immune system responses that led to increase in the number of lymphocytes in the primary lymphoid organs. These results may imply that broilers fed acidifiers diets obtained higher immune response and disease resistance. In this respect, Katanbaf et al. (1989) reported that increases in the relative lymphoid organs weights are considered as an indication of the immunological advances. The fact of thyroid hormones as a major role in regulating oxidative metabolism of birds has been established (Sturkie, 1999). Triiodothyronine $\left(\mathrm{T}_{3}\right)$ level, as the metabolic activity of thyroid hormone, plays an active role in energy metabolism and metabolic rate. Any pronounced alteration in thyroid function (hyperthyroidism or hypothyroidism) is reflected in alteration of metabolic rate. Our results pointed out superior metabolic and growth rate due to the addition of acidifiers into broiler chickens diet. The hyperthyroidism and peripheral conversion of $\mathrm{T}_{4}-\mathrm{T}_{3}$ was signified better. The concentration of thyroid hormones circulating in chicken blood plasma was found to be around $1.2 \mu \mathrm{L} / 100 \mathrm{~mL}$ (Davison, 1976), showing daily variations due to an extremely short half-life and showing $\mathrm{T}_{3}-\mathrm{T}_{4}$ ratio to be 60:40, in favor of $\mathrm{T}_{4}$ (Mehner and Hartfiel, 1983).

Similar results with the present study were found by Abdel-Fattah et al. (2008). In contrast, other studies, in which ascorbic acid and citric acid (Brown and Southern, 1985) were added to broiler diets, indicated that experimental treatments of intestinal content $\mathrm{pH}$ levels were not different compared to control that did not support our results. Decreasing pH in GI-tract had a beneficial effect in the inhibition of intestinal bacteria competition with the host for available nutrients and the possibility of reducing bacterial toxicity, e.g., ammonia and amines, thus improving weight gain of the host animals. Furthermore, the growth inhibition of potential pathogen bacteria, e.g. E. coli and Salmonella, in the feed and GI-tract is beneficial in respect to animal state of health (Thompson and Hinton, 1997). Organic acids are not antibiotics but, if used correctly along with proper nutritional, managerial and biosecurity measures, they can be a powerful tools in maintaining the GI-tract poultry state of health, thus improving their zootechnical performances. If applied correctly, organic acids function in poultry, not only as a growth promoter but also as a meaningful mechanism for controlling both pathogenic and non-pathogenic bacteria (Wolfenden et al., 2007). Moreover, feeding organic acids are believed to have several beneficial effects such as improving feed conversion ratio, growth performance, enhancing mineral absorption and speeding recovery from fatigue (Zeinb, 2004; Nourmohammadi et al., 2010b). The antibacterial activity of organic acids is related to reduction of $\mathrm{pH}$, as well as their ability to dissociate that is determined by the pKa-value of the respective acid and $\mathrm{pH}$ of the surrounding environment, because the antibacterial activity increases with decreasing $\mathrm{pH}$ value. Several investigations have shown a strong bactericidal effect of organic acid without significantly decreasing the $\mathrm{pH}$ value in the GI-tract. Generally lactic acid bacteria are able to grow at relatively low $\mathrm{pH}$ which means that they are more resistant to organic acids than other bacterial species, e.g., E. coli (Russell and Diez-Gonzalez, 1998). In poultry, pathogenic bacteria e.g. Salmonella enters the GI-tract via crop. The crop environment with respect to microbial composition and $\mathrm{pH}$ seems to be very important in relation to the resistance to pathogens. High amounts of Lactobacilli and low $\mathrm{pH}$ in the crop have shown to decrease the occurrence of Salmonella in the crop (Hinton et al., 2000). Also the antibacterial effect of dietary organic acids in chickens is believed to take place mainly in the upper part of the digestive tract (crop and gizzard). Therefore, following combination addition of formic and propionic acid (Bio-Add) in high concentrations could only be affected by crop and gizzard (Thompson and Hinton, 1997).

\section{CONCLUSION}

Using organic acid and phytase supplementation as physiological additives might be useful to promote the immune response of broilers through their physiological action effect on the growth activities of some endogenous mechanisms responsible for better growth performance. As well, under the condition of this experiment, depression of $\mathrm{pH}$ values of GI-tract parts 
by $\mathrm{CA}$ that can be a powerful tool in maintaining the GI-tract poultry state of health, thus improving weight gain of the broilers.

\section{ACKNOWLEDGMENT}

The researchers gratefully acknowledge the excellent financial and technical assistance of Birjand University.

\section{REFERENCES}

Abdel-Fattah, S.A., M.H. EI-Sanhoury, N.M. EI-Mednay and F. Abdel-Azeem, 2008. Thyroid activity, some blood constituents, organs morphology and performance of broiler chicks fed supplemental organic acids. Int. J. Poult. Sci., 7: 215-222.

Al-Natour, M.Q. and K.M. Alshawabkeh, 2005. Using varying levels of formic acid to limit growth of Salmonella gallinarum in contaminated broiler feed. Asian-Austal. J. Anim. Sci., 18: 390-395.

Brenes, A., A. Viveros, I. Arija, C. Centeno and M. Pizarro et al., 2003. The effect of citric acid and microbial phytase on mineral utilization in broiler chicks. Anim. Feed Sci. Technol., 110: 201-219. DOI: 10.1016/S0377-8401(03)00207-4

Brown, D.R. and L.L. Southern, 1985. Effect of citric and ascorbic acids on performance and intestinal pH of chicks. Poult. Sci., 64: 1399-1410. PMID: 4022914

Chesson, A., 1993. Feed enzymes. Anim. Feed Sci. Technol., 45: 65-79.

Darras, V.M., T.J. Visser, L.R. Berghman and E.R. Kuhn, 1992. Ontogeny of type I and type III deiodinase activities in embryonic and posthatch chicks: Relationship with changes in plasma triiodothyronine and growth hormone levels. Comp. Biochem. Physiol. Comp. Physiol., 103: 131-136. PMID: 1356690

Davison, T.F., 1976. Circulating thyroid hormones in the chicken before and after hatching. General and Comp. Endocrinol., 29: 21-27. PMID: 59679. DOI: 10.1016/0016-6480(76)90003-4

Hinton, A.Jr., R.J. Buhr and K.D. Ingram, 2000. Reduction of Salmonella in the crop of broiler chickens subjected to feed withdrawal. Poult. Sci., 79: 1566-1570.

Katanbaf, M.N., E.A. Dunnington and P.B. Siegel, 1989. Restricted feeding in early and latefeathering chickens. 1. Growth and physiological responses. Poult. Sci., 68: 344-351. PMID: 2704691

Kemme, P.A., A.W. Jongbloed, Z. Mroz and A.C. Bryden, 1998. Diurnal variation in degeradation of phytic acid by plant phytase in the pig stomach. Livest. Prod. Sci., 5:33-34. DOI: 10.1016/S03016226(97)00163-2
Lowe, J.T., H. Steenbock and C.H. Keiger, 1939. Cereals and rickets. IX. The availability pf phytinP to the chick. Poult. Sci., 18: 40-44.

Mehner, A. and W. Hartfiel, 1983. Handbuch der Geflügelphysiologie. 1st Edn., Karger, ISBN-10: 3805537387 , pp: 1156.

Nourmohammadi, R., S.M. Hosseini and H. Farhangfar, 2010a. Effect of dietary acidification on some blood parameters and weekly performance of broiler chickens. J. Anim. Vet. Adv., 9: 3092-3097. DOI: $10.3923 /$ javaa.2010.3092.3097

Nourmohammadi, R., S.M. Hosseini and H. Farhangfar, 2010b. Influence of citric acid and microbial phytase on growth performance and carcass characteristics of broiler chickens. Am. J. Anim. Vet. Sci., 5: 282-288. DOI: 10.3844/ajavsp.2010.282.288

Ravindran, V., S. Cabahug, G. Ravindran, P.H. Selle and W.L. Bryden, 2000. Response of broiler chickens to microbial phytase supplementation as influenced by dietary phytic acid and non-phytate phosphorus levels. II. Effects on apparent metabolisable energy, nutrient digestibility and nutrient retention. Br. Poult. Sci., 41:193-200. PMID: 10890216

Russell, J.B. and F. Diez-Gonzales, 1998. The effects of fermentation acids on bacterial growth. Adv. Microb. Physiol., 39:205-234. PMID: 9328648

SAS Institute, 2000. SAS SQL Procedure User's Guide. 1st Edn., SAS Institute Inc., Cary, NC, USA., ISBN-10: 158025599X, pp: 576.

Sebastian, S., S.P. Touchburn, E.R. Chavez and P.C. Lague, 1996. The effects of supplemental microbial phytase on the performance and utilization of dietary calcium, phosphorus, copper, and zinc in broiler chickens fed corn-soybean diets. Poult. Sci., 75: 729-736. PMID: 8737837

Sturkie, P.D., 1999. Avian Physiology. 5th Ed. National Academy Press, Inc., New Work, NY., ISBN-13: 9780127476056, pp: 704.

Thompson, J.L. and M. Hinton, 1997. Antibacterial activity of formic and propionic acids in the diet of hens on salmonellas in the crop. Br. Poult. Sci., 38: 59-65. PMID: 9088614

Viveros, A., C. Centeno, A. Brenes, R. Canales and A. Lozano, 2000. Phytase and acid phosphatase activities in plant feedstuffs. J. Agri. Food Chem., 48: 4009-4013. DOI: 10.1021/jf991126m

Warden,W.K. and P.J. Schaible, 1962. Preliminary investigations concerning utilization of phytin phosphorus by the chick. Poult. Sci. 41: 1692. 
American J. Animal \& Vet. Sci., 6 (1): 1-6, 2011

Wolfenden, A.D., J.L. Vicente, J.P. Higgins, R.L.A. Filho and S.E. Higgins et al., 2007. Effect of Organic Acids and Probiotics on Salmonella enteritidis Infection in Broiler Chickens. Int. J. Poult. Sci., 6: 403-405.
Zeinb, A.M.A., 2004. Efficacy of acetic acid in improving the utilization of low protein-low energy broiler diets. Egypt. Poult. Sci., 24: 123-141. 